\title{
The Influence of Father Involvement and Sibling Relationship Toward Social Skill of Siblings of Intellectual Disability
}

\author{
Indira Wulandari Pratiwi \\ Faculty of Psychology \\ Syarif Hidayatullah State Islamic University (UIN) \\ Jakarta, Indonesia \\ pratiwiindira90@gmail.com
}

\author{
Neneng Tati Sumiati \\ Faculty of Psychology \\ Syarif Hidayatullah State Islamic University (UIN) \\ Jakarta, Indonesia \\ neneng.tati@yahoo.com
}

\begin{abstract}
The purpose of this research to find out the influence of father involvement variable and sibling relationship. The sample amount of 108 siblings of intellectual disability in DKIJakarta which were taken with snowball sampling and accidental sampling. Measuring instrument for validity test used confirmatory factor analysis (CFA). Data analysis used multiple regression analysis technique. The result shown that there was significant effect of father involvement and sibling relationship on social skill of siblings of intellectual disability. The result shown variance proportion of social skill which was explained in all independent variables was 49,0 \% while $51,0 \%$ was influenced by external variable of this research. In this research was found that the most contribution of the variable was father involvement amount $38,9 \%$. Suggestion from this research is father is expected could actively involved in child rearing process so that children social skill can develop well.
\end{abstract}

Keywords: Social Skill; Father Involvement; Sibling Relationship

\section{INTRODUCTION}

The number of persons with mental retardation in Indonesia is an interesting phenomenon to study.Nahar (Director of ODK Hospital) at the opening of the Accessibility Accessibility Technical Guidance program in 2015, based on the National Socio-Economic Survey (Survey Sosial Ekonomi Nasional) conducted by the Biro Pusat Statistik (BPS) in 2012, stated that the number of persons with disabilities in Indonesia is 6,008,661 people. About 402,817 persons with intellectuals disabilities (www.ppid.kemsos.go.id, 2016).

Families who have intellectual disability member, reported have several problems both internal and external to the family. Families with Down syndrome children are reported they have higher levels of stress and lower life satisfaction [1]. Parents with Down syndrome experience distress caused by child behavior problems. In addition, the problem is not only faced by the parents, but also the siblings [1]. In a previous study Lobato et.al reported the siblings are more at risk for emotional and behavioral problems. Thery also reported more aggression ini siblings. While [2] agree that siblings intellectual disablity have social adjustment. In general, the higher the functional level of the afflicted child, the better the sibling's adjustment. Cuzzocrea, et al in his research found that siblings of intelctual disability tend to be aggressive because of the difficulty of having a relationship with the father, other than that children who have difficulty having a good relationship with their mothers tend to be depressive and avoid interaction with peers and also his teacher.

These problems then affect to social skills of siblings of Intellectual disabilities The study of social skills is important because. If social skills do not developed properly, it would impact on the destruction of individual relationships with other individuals, the failure of academic and work achievement, to trigger violence in society and other adverse effects. Jones et al found inhibited sociabillity could impact social skill inadequacies including passiity, lack of assertiveness, greater shyness, and self-consciousness, and problems study to lonely adolescents and college students[3].

Hurlock [4] states that one of the important outcomes a child must have is social maturity not only includes intelligence and motor skills but also other things such as being able to accept outsiders, awareness of duties, obedience to rules and controlling emotions and the child can adapt to the group's agreed standards in appearance, speech and behavior, so that age is also called age adjust. Various studies show the importance of social skills in adolescents. Spitzberg [5] states there is sufficient empirical evidence that links social competence to mental and physical health. Lack of social skills might impact to disorders as an anxiety, cariovascular disease, juvenile deliquency, and substance abuse [5]. The results of Hecht $\&$ Wittchen [5] recent estimates indicate that between 7 and $10 \%$ of the population has difficulties with social interaction skills and may be considered socially incompetent. Jackson and Bijstra [6] agree that in some previous studies the lack of social skills in a teenager will have an impact on loneliness, juvenile delinquency, poor adaptability, poor academic performance and weakness mental health.

Besides being influanced by internal individual factors, social skills are also influenced by factors outside the individual such as the parent. Fathers and mothers play an important role in individual growth. In the previous 
study, Allen and Dally [7] mentioned father involvement is positively correlet with children's overall social skill, social nitiative, social maturity, and capacity relatedness with others. Children of fathers who are involved in parenting have more positive peer relationships, becoming popular and preferred. Relationships with peers are characterized by a lack of negative relationships, aggression, or conflict, more generous attitudes and the ability to make positive friendships.

Beside parental factor, relationships with siblings also become important of social skill development. Adolescence is an important period for the learning and development of social skills. As young people enter adolscence, they meet a range of new social situation and roles with which they have to deal. In order to fullfill this task, adequate social skills are required [6]. Various research states that, good siblings relationship has a positive impact on the social relationships of children with friends, social adjustment, and moral development of children[6]. According to Hetherington, younger siblings who experience a balance of nurturance and conflict in their sibling relationship have been found to be more socially skilled and have more positive peer relationships compare children who lack of this.

We hypothesized that: a) father involvement would positively and significantly impact toward social skills, and b) warmth and closeness sibling relationship would positively and significantly impact toward social skills.

\section{METHODS}

The population used in this study, men and women who livein DKI Jakarta. The sample to be used is representative of the early adolescence until the late adolescence both men and women aged 12 to 21 years who have siblings with intellectual disability.The sampling technique in this research is using non probability which that is accidental sampling and snowball sampling. The population technique used by the researcher is accidental sampling where the researcher took the sample which happened by using the spread of questioner online, this study also used the snowball sampling technique by the researcher find the sample according to the criterion, then the researcher asked the sample to find other respondents which match the sampling criteria.

Social Skills Inventory Scale, adapted by developing the Social Skill Theory of Riggio [8]. This scale measure six dimensions: emotional expressivity, emotional control, emotional sensitivity, social expressivity, social sensitivity, and social control. This instrument consists of 36 items statement, and has four response catagories: 1.really disagree, 2.disagree, 3.Agree, 4 . Really agree. The Father Involvement Scale researchers adapted by developing nine dimensions of father involvement [6]. This instrument measures 9 dimensions: dicipline and teaching responsibility, mother support, school encouragement, providing, time and talking together, prise and affection, developing talents and future concerns, reading and homework support, attentiveness. This measuring tool consists of 75 items of statement, but in this study used 35 statements. Measurement sibling relationship researchers adapting measuring tool Sibling Relationship Questioner [9] This measure consists of 48 items to measure 4 dimensions: warmth/closeness, relative power status, Conflict, and rivalry. However, this study only measure the dimensions of warmth/closeness and conflict.

\section{RESULT AND DISCUSSION}

To test the validity of the measuring instrument, researchers tested with Confirmatory Factor Analysis. Based on the results of CFA on social skills measurement, obtained a one-factor model with 6 dimensions consisting of 36 items and 10 items stated fit, with Chi-Square = $35.808, \mathrm{df}=35 \mathrm{p}$-value $=0.4303$, RMSEA $=0,000$. On variablefather involvement 1 factor with 1 dimension is unidimensional consisting 35 items and 12 items valid with Chi-Square $=71,097, \mathrm{df}=50, \mathrm{p}$-value $=0,265$, and RMSEA $=0,02$. In variable warm and Closeness obtained value RMSEA $=0.000$, Chi-Square $=12.247, \mathrm{df}=14$, and $\mathrm{p}$-value $=0.5865$. While in conflict variable after one time do modification obtained value RMSEA $=0.000$, ChiSquare $=2.726, \mathrm{df}=2$, and $\mathrm{p}$-value $=0.2559$.

The proportion of social skills variance explained by all independent variables in this study is 0.490 or about $49 \%$ (see on tabel 1.0). This means that the variation of social skills variables is caused by independent variables in this study, while the remaining $51 \%$ (1-49\%) variation in social skills is caused by other variables outside this study. Considering the effect of all IV on DV, this study has significance $(p<0.05)$, meaning that there is significant influence between father involvement, warmth and closeness, and conflict on social skills. Looking at the independent regression coefficient variable to dependent variable can be seen that the variable father involvement has a regression coefficient of 0.496 and $\mathrm{Sig}=0.00$ ( $\mathrm{Sig}$ $<0.05$ )(see on tabel 2.0), in other word if fathers being highly involved in childrens life, children also have higher social skill. This means that father involvement has a positive and significant influence on social skills. Then the variable warmth and closeness to social skill has regression coefficient of 0.326 and $\mathrm{Sig}=0.00$ ( $\mathrm{Sig}<0.05$ ). This means that warmh and closeness has a positive and significant influence on social skills, in othe word if siblings has high warmth and closeness relationship witth their intellectual disability sibling, children also higher social skill. Conflict variable to social dimension has regression coefficient of 0.92 and $\mathrm{Sig}=0.072(\mathrm{Sig}>0.05)$ means that there is no significant influence of conflict to social skill of siblings. In this study, the father involvement has the largest variance proportion of $39.5 \%$ and the warmt and closeness has $8.7 \%$ variance proportion.

Table 1.0 Modal Summary 


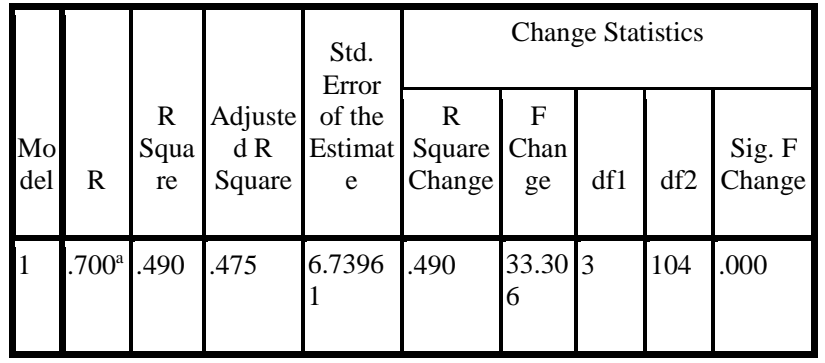

a. Predictors: (Constant), T.C, T.WC, T.FI

Table 2.0 Model Summary

\begin{tabular}{|c|c|c|c|c|c|c|c|c|c|}
\hline \multirow[b]{2}{*}{$\begin{array}{l}\text { Mo } \\
\text { del }\end{array}$} & \multirow[b]{2}{*}{$\mathrm{R}$} & \multirow[b]{2}{*}{$\begin{array}{c}\mathrm{R} \\
\text { Squa } \\
\text { re }\end{array}$} & \multirow[b]{2}{*}{$\begin{array}{c}\text { Adjuste } \\
\text { d R } \\
\text { Square }\end{array}$} & \multirow{2}{*}{$\begin{array}{c}\text { Std. } \\
\text { Error of } \\
\text { the } \\
\text { Estimat } \\
\text { e }\end{array}$} & \multicolumn{5}{|c|}{ Change Statistics } \\
\hline & & & & & $\begin{array}{c}\text { R } \\
\text { Square } \\
\text { Change }\end{array}$ & $\begin{array}{c}\text { F } \\
\text { Chan } \\
\text { ge }\end{array}$ & df1 & df2 & $\begin{array}{c}\text { Sig. F } \\
\text { Change }\end{array}$ \\
\hline 1 & $.629^{\mathrm{a}}$ & .395 & .389 & $\begin{array}{r}7.2708 \\
2\end{array}$ & .395 & $\begin{array}{r}69.21 \\
1\end{array}$ & 1 & 106 & .000 \\
\hline 2 & $.694^{b}$ & .482 & .472 & $\begin{array}{r}6.7594 \\
9\end{array}$ & .087 & $\begin{array}{r}17.64 \\
3\end{array}$ & 1 & 105 & .000 \\
\hline 3 & $.700^{c}$ & .490 & .475 & $\begin{array}{r}6.7396 \\
1\end{array}$ & .008 & 1.620 & 1 & 104 & .206 \\
\hline
\end{tabular}

a. Predictors: Father Involvement

b. Predictors: Warmt and closeness

c. Predictors: Conflict

\section{DISCUSSION}

A large number of studies have tested the hypothesis that positive father involvement benifits children. The results of the analyses reported that Fathers' involvement has significant impact toward social skills, it be relevant according prior research, that father involvement is positively correlated to social competence, social initiative, social maturity (Allen \& Daly, 2007).[7] In addition, negative father involvement, such as high hatred has significant impact on negative social behavior during adulthood (Allen \& Daly, 2007). The limitation of this research is, this study not provide the dimension of father involvement that really have biggest variance cotribution toward social skill.

Several bodies of research now indicate that the quality of sibling relationship is related of childrens social development.We then examined two sibling relationship dimension is warmth and closeness and conflict. Warmth and closeness dimension on the sibling relationship has positive and significant impact toward social skills. This result is relevant according prior research (Stoneman \& Brody, 1993) where the study found sibling relationship that are positive or have a high degree of warm and closeness will make the older brother take care of the younger brother, and younger brother will love the older brother, so they have a stronger social ties to environment. Seginer (1988) also found that warmt ini adoscents sibling relationship predicted adolscents perceptions of emotional support they received from peers and school-related support in general. According to Volling \& Blandon [9] older adolscents with warm and supportive sibling relationships during childhood reported higher self-esteem, greater perceived competence in their abilities and social competence with peers than those adolecents with litle sibling support This study contains several limitations, how ever. First, social skill Questionaire that being used in this research, did not ask questions about subject interaction with theit peers. Wheareas, how important to know the quality of their relationship with peers to know how good their social skill applied into socal life. Second limitation in this research is, we did not used proper sibling relationship measurement, because Sibling Relationship Questionaire, not assess sibling relationship in families with handicaped child. Wheareas, it how important to know subjects acceptence to their intellectual disability sibiling.

\section{CONCLUSIONS}

In this study, father involvement and warmth and closeness positively significant affects the social skill of the mentality of the person with intellectual disability. The effect of Independent Variable on overall Dependent Variable is $49 \%$. Further research is expected to examine with larger samples or different characteristic sibling such as autism, deaf, aqueduct, or other disabilities. In addition, it is expected to use a valid and more concise father involvement item to minimize bias in answering the questionaire.

\section{REFERENCES}

[1] C. C. Cunningham, Families of Children with Down Syndrome. Liverpool: Moores University, 1996.

[2] V. G. Cicirelli, Sibling Relationship Across The Life Span. New York: Science-Bussiness Media, 1995.

[3] W. Jones, S. . Hobbs, and D. Hockenbury, "Loneliness and Social Skills Deficits. Journal of Personality and Social Psychology.," 1982.

[4] E. Hurlock, Psikologi Perkembangan: Suatu Pendektan sepanjang rentang kehidupan, Kelima. Jakarta: Publisher, 1993.

[5] M. S. Clikeman, Social Competence in Children. Michigan: Springer Science. Michigan: Spinger Science, 2007.

[6] B. J and J. S, Social skills and psycho-social functioning ini early adolescene: a three-year follow up. Groningen, The Netherlands. Groningen, The Netherlands, 1995.

[7] A. S and K. Daly, "The Effect of Father Involvement: An Update Research Summary of Evidance.," Father Involv., 2007.

[8] R. . Riggio, Assessment pf Basic Social Skills. Journal of Personality and Social Psychology. .

[9] B. Volling and A. Blandon, Positive Indicators of Sibling Relationship Quality : Psychometric Analyses of the Sibling Inventory of Behavior (SIB). Child Trends. 